\title{
Common Hawailan Words Used in the Text
}

ahupua'a. Land division usually extending from the mountain to the sea.

'Ewa. Place name west of Honolulu used as a direction term.

haole. White person; formerly it was used to indicate any foreigner.

heiau. Pre-Christian place of worship; some heiau were elaborately constructed stone platforms, other simple earthen terraces.

hukilau. A seine; the method of fishing with the seine.

imu. Underground oven.

kahuna. Priest, minister, sorcerer.

kama‘āina. Native-born; lit., land child.

kapu. Taboo, prohibition.

konohiki. Headman of an ahupua' $a$ under the chief; also land or fishing rights under control of the konohiki.

kuleana. A small piece of property within an ahupua'a.

kupua. Demigod, especially a supernatural being possessing several forms.

lae. Cape, point, promontory. lānai. Porch, veranda.

limu. A general name for all kinds of plants living underwater, both fresh and salt; a common term for seaweed.

lū'au. Young taro tops, especially as cooked with chicken or octopus; Hawaiian feast, named after the taro tops always served at one.

makai. Toward the sea, in the direction of the sea.

mauka. Inland, upland, toward the mountains.

menehune. Legendary race of small people who worked at night, building fish ponds, roads, temples.

mo'o. Lizard, reptile of any kind.

muliwai. Pool near the mouth of a stream, as behind a sandbar, often enlarged by ocean water left by high tide.

'opihi. Limpet.

paniolo. Cowboy (probably from the Spanish español).

papa. A flat section of ocean bottom, such as a shelf or reef.

Pele. The goddess of the volcano.

wana. A sea urchin. 
